\title{
Kepemimpinan Yosia Berdasarkan Kitab 2 Tawarikh 34:1-7 Dan Implikasi Bagi Kepemimpinan Pemuda di Gereja
}

\section{Josiah's Leadership Based on the Book of 2 Chronicles 34: 1- 7 And the Implications for Youth Leadership in the Church}

\author{
Delvy Fransisca ${ }^{1 *}$ \\ Yunus D. A. Laukapitang ${ }^{2)^{*}}$ \\ 1) Mahasiswa Pascasarjana Sekolah Tinggi Filsafat Theologia Jaffray Makassar \\ * Penulis Korespondensi: delvyfransisca97@gmail.com \\ 2) Dosen Sekolah Tinggi Filsafat Theologia Jaffray Makassar \\ *Penulis Korespondensi: nus_lau@yahoo.com
}

Received: 2607 2020/ Accepted:10 12 2020/ Published: 11122020

\begin{abstract}
Abstrak
Tujuan penulisan artikel ini adalah pertama, untuk memberikan penjelasan secara Alkitabiah tentang kepemimpinan Yosia berdasarkan kitab 2 Tawarikh 34:1-7. Kedua, untuk memberikan penjelasan tentang implikasi kepemimpinan Yosia bagi kepemimpinan pemuda di gereja. Adapun metode penulisan adalah metode kualitatif, yaitu dengan mencari makna dari kepemimpinan Yosia berdasarkan kitab 2 Tawarikh 34:1-7 dengan menggunakan penalaran induktif, eksegesis serta studi kepustakaan. Kesimpulan dari artikel ini adalah sebagai berikut. Pertama, Tuhan memakai kaum muda. Hal ini menjadi dorongan besar bagi gereja seharusnya untuk mampu melibatkan pemuda lebih lagi dalam gereja dan dalam pelayanan. Kedua, dalam kaitannya bagi kepemimpinan pemuda, pemimpin harus memusatkan hidup pada Tuhan. Seorang pemimpin mengejar kekudusan, kejujuran dan perkenanan Tuhan. Ketiga, berkaitan dengan kepemimpinan pemuda, pemimpin harus siap menghadapi tantangan. Tantangan baik dari teknologi maupun tantangan kekuasaan dalam gereja.
\end{abstract}

Kata-kata Kunci: 2 Tawarikh 34:1-7, Gereja, Kepemimpinan, Pemuda, Yosia.

\begin{abstract}
The purpose of writing is first, to give a biblical explanation of Josiah's leadership based on 2 Chronicles 34:1-7. Second, to provide an explanation of the implications of Josiah's leadership for youth leadership in the church. The writing method is a qualitative method, namely by searching for the meaning of Josiah's leadership based on 2 Chronicles 34:1-7 by using inductive reasoning, exegesis and literature studies. The conclusion of this article is as follows. First, God uses young people. This is a big impetus for the church to be able to involve youth more in the church and ministry. Second, concerning youth leadership, leaders must focus their lives on God. A leader
\end{abstract}


pursues holiness, honesty and God's favor. Third, still concerning youth leadership, leaders must be ready to face challenges. Challenges both from technology and challenges to power in the church.

Keywords: 2 Chronicles 34:1-7, Church, Josiah, Leadership, Youth.

\section{PENDAHULUAN}

Gereja tidak terlepas dari kepemimpinan. Kepemimpinan di gereja memberi pengaruh kepada setiap orang untuk mencapai tujuan yang telah ditetapkan oleh gereja yaitu mengarahkan hidupnya kepada Yesus Kristus. Seiring berjalannya waktu dan berkembangnya zaman, maka orang-orang yang terlibat dalam kepemimpinan gereja juga akan terjadi pergantian. Ini yang disebut dengan generasi penerus. Kaum muda akan mengganti kaum tua dalam kepemimpinan di gereja.

Gereja membutuhkan generasi penerusnya. Kaum muda dalam gereja adalah generasi penerus itu. Kaum muda memiliki peran yang sangat penting dalam perkembangan kehidupan, harapan dan masa depan gereja. Keberadaannya menjadi bagian yang tidak terpisahkan dari gereja itu sendiri (Mahda, 2017, p. 129). Para pemuda di gereja secara mutlak akan menjadi generasi penerus atau generasi masa depan itu. Jika tidak ada generasi penerus, maka gereja akan hilang karena tidak ada yang meneruskan.

Kaum muda seringkali rentan dalam mengalami penindasan hak-hak asasi. Hal itu terjadi karena posisi anak-anak muda sangat bertentangan antara bahasa, nilainilai, kebiasaan yang ada di dalam komunitasnya dan yang ada di masyarakat luas (Rahzen dan Hartono, 2011, p. 52). Tidak hanya masyarakat luas, gereja juga termasuk dalam penindasan hak asasi anak-anak muda. Gereja seringkali menganggap bahwa segala kegiatan dan program yang diadakan oleh kaum muda kurang penting, akhirnya ditolak oleh gereja dan majelis sendiri (Tacoy, 2009, p. 40). Kaum muda dianggap tidak mampu karena memiliki sifat yang amatiran, karena sedang mencari jati diri dan cenderung berbuat salah. Yang gereja takutkan adalah kaum muda akan membawa kehancuran bagi kudusnya gereja, sehingga gereja selalu menghakimi anak-anak muda atas perbuatannya (Lie, 2017, p. 210). Gereja tidak menghargai kemampuan yang dimiliki oleh anak-anak muda sehingga membuat anak-anak muda tidak bisa menjadi pemimpin. Kaum muda itu beranggapan bahwa orang dewasa tidak akan menganggapnya sebagai pemimpin, bahkan anak-anak muda akan berpikiran "apakah yang bisa dilakukan oleh orang seusiaku?" Ketidakmampuan dan rasa minder menjadi pemimpin karena usia yang belum cukup atau masih muda yang dipermasalahkan oleh orang dewasa dalam gereja (Maxwell, 2014, p. 3).

Situasi itu juga disetujui oleh anak-anak muda dari beberapa gereja. Penulis juga melakukan wawancara awal kepada para ketua pemuda, anggota pemuda 
bahkan kaum muda yang terlibat dalam pelayanan di gereja. Dari wawancara tersebut beberapa narasumber mengatakan bahwa kepemimpinan pemuda di gereja terkadang dianggap tidak baik bagi gereja. Pemuda membuat suatu cara yang kreatif tetapi dianggap membawa hal yang duniawi ke dalam gereja. Para pemimpin pemuda mencoba untuk kontekstual terhadap kehidupan anggotanya karena sambil mencari cara menjangkau para anak muda tersebut tetapi dituduh melakukan hal yang menyimpang dari gereja, seperti nongkrong di kafe, dsb. Ada juga yang mengatakan bahwa para generasi tua di gereja selalu menuntut program pemuda tetapi tidak pernah memberikan solusi untuk pemuda. Akhirnya, semakin lama gereja tersebut sering terjadi konflik antar organisasi.

Masalah pemuda dalam hal kepemimpinan lainnya adalah penolakan ide. Tidak sedikit pemuda yang memunculkan ide-ide pelayanan yang berbeda, hal ini yang terkadang memicu permasalahan dengan pemimpin senior. Perbedaan pandangan sering memicu adanya pertentangan antara majelis dengan pemuda. Tidak heran jika pemuda menjadi dingin dan suam serta kurang semangat dalam hal keterlibatannya di gereja. Peran gereja sekali lagi tidak bisa mendewasakan pemudanya dengan baik dalam hal kepemimpinan.

Dalam Alkitab juga tercatat ada seorang pemimpin yang masih sangat muda belia. Pada masa pemerintahannya, ia memiliki pengaruh yang besar. Pemimpin itu adalah raja Yosia. Yosia berumur delapan tahun ketika diangkat menjadi raja atas Yerusalem (2 Taw. 34:1). la bahkan melakukan penghancuran penyembahan berhala yang ada di negerinya (34:4-7). Sangat tidak masuk akal bagi seorang anak berumur delapan tahun memimpin suatu kerajaan. Akan timbul pertanyaan dari setiap orang, "Apa yang bisa dilakukan oleh anak itu?" atau "Bagaimana cara kepemimpinannya?" Yosia adalah raja saleh terakhir dari Yehuda, dan di dalam hal tertentu ia juga merupakan Raja Yehuda yang terbesar (Pfeiffer dan Harrison, 2004, p. 1122).

Keadaan Yehuda pada saat itu sangatlah kacau. Raja-raja sebelum Yosia mengalami pasang surut ketaatan kepada Allah. Banyak dari raja-raja itu melakukan penyembahan berhala dan menyimpang dari Tuhan termasuk kakek dari Yosia, raja Manasye dan ayah Yosia, raja Amon. Tetapi Yosia (2 Taw. 34:1) yang adalah anak dan cucu dari seorang penyembah berhala, tidak melakukan penyembahan tersebut. Tidak diketahui siapa yang mendidik dan membina Yosia dalam masa pertumbuhannya, tetapi ia dikatakan melakukan sesuatu yang benar di mata Tuhan (ay. 2). Bahkan dalam masa pemerintahannya, ia melakukan sesuatu yang dianggap tidak biasa dengan usia yang masih muda untuk dilakukan (ay. 3-5). Tidak ada raja seperti Yosia setelah dan sebelum ia, seperti yang dikatakan dalam 2 Raja-raja 23:25, "Sebelum dia tidak ada raja seperti dia yang berbalik kepada TUHAN dengan segenap hatinya, dengan segenap jiwanya dan dengan segenap kekuatannya, sesuai dengan segala Taurat Musa; dan sesudah dia tidak ada bangkit lagi yang seperti dia." Hal ini yang menarik perhatian penulis, seorang raja berumur delapan tahun, memerintah selama tiga puluh satu tahun, dan berhasil dalam pemerintahannya. 
Dalam artikel ini, penulis akan membahas mengenai kepemimpinan Yosia berdasarkan 2 Tawarikh 34:1-7.

\section{METODE}

Metode penelitian yang digunakan ialah metode kualitatif dengan penalaran induktif. Penalaran induktif adalah suatu kegiatan berpikir yang berhubungan dengan penarikan kesimpulan dari kasus yang bersifat khusus ditarik menjadi kesimpulan yang bersifat umum (Lumintang dan Lumintang, 2016, p. 95). Selain itu penulis juga melakukan eksegesis terhadap teks 2 Tawarikh 34:1-7. Metode penelitian literatur (kepustakaan) juga penulis libatkan, yaitu mengumpulkan data dari buku-buku dan sumber lain yang membahas tentang Yosia.

\section{HASIL DAN PEMBAHASAN}

\section{Analisis Tentang Kepemimpinan Yosia Berdasarkan Kitab 2 Tawarikh 34:1-7}

2 Tawarikh 34:1-7 merupakan salah satu pasal dalam Perjanjian Lama yang memperlihatkan tentang kepemimpinan salah satu raja di Yehuda. Seperti yang diketahui sebelumnya bahwa kepemimpinan raja di Israel bagian selatan maupun utara ini mengalami penyimpangan terhadap peribadatan kepada Allah. Banyak dari raja-raja ini yang mengikuti para pendahulunya untuk menyembah ilah-ilah lain. Pasal ini menuliskan tentang seorang raja yang sangat muda tetapi berhasil dalam menggagalkan penyembahan berhala di wilayah pemerintahannya.

Kitab Tawarikh khususnya dalam pasal 34:1-7 menuliskan tentang seorang raja muda yaitu Yosia dalam kepemimpinannya sebagai pemimpin muda dan tindakannya membersihkan penyembahan berhala atau mezbah-mezbah para Baal di daerah Yehuda dan beberapa daerah Israel (Bergant dan Karris, 2002, p. 347). Raja Yosia berusaha memimpin rakyatnya untuk kembali menyembah Allah. Bahkan ia adalah raja yang paling dicintai rakyatnya di Yehuda (Frances, 2007, p. 200). Untuk itu dalam penulisan artikel ini sangat penting bagi penulis untuk memahami bagaimana kepemimpinan Yosia berdasarkan kitab 2 Tawarikh 34:1-7.

\section{Yosia Merupakan Pemimpin Muda (ay. 1)}

Dalam 2 Tawarikh 34:1, Yosia diangkat menjadi raja ketika ia berumur delapan tahun. Kata "ia menjadi raja" dalam teks Ibrani בָָּ maw-lak yang memiliki arti yaitu "memerintah." la berusia delapan tahun menunjukkan bahwa ia adalah seorang anak, masih sangat muda (Bibleworks 7, s.v. מָלָ). Yosia sudah menjadi raja dan memerintah sejak ia berumur delapan tahun. Bahkan ia berhasil dalam masa pemerintahannya selama tiga puluh satu tahun.

Yosia menjadi raja dengan usia semuda itu tidak dikatakan apa alasannya. Tetapi bahwa ia naik takhta pada umur 8 tahun, adalah jasa 'rakyat negeri itu', yang membunuh orang-orang yang membunuh ayahnya juga (2 Raj. 21:24; 2 Taw. 33:25; 
Douglas, 1995, p. 626). Kekacauan yang terjadi di negeri itu karena dibunuhnya raja Amon, rakyat negeri itu sendiri yang mengangkat Yosia menjadi raja. Dengan demikian penulis mengambil kesimpulan bahwa rakyat membutuhkan raja untuk memerintah atas bangsa itu seperti yang dikatakan orang Israel kepada Samuel dalam 1 Samuel 8:5. Tetapi kemungkinan besar dan bahkan hal yang lebih pasti, Yosia menjadi raja itu karena Allah. Seorang abdi Allah telah menubuatkan bahwa akan ada seorang anak lahir pada keluarga Daud yang mana nubuat itu adalah perintah langsung dari Tuhan untuk abdi Allah itu katakan (1 Raj. 13:2).

Arti nama Yosia adalah "ia yang didukung Allah" atau "Allah menopang" (Lasor, Hubbard, dan Bush, 2008, p. 368). Yosia memiliki usia di mana ia sangat mudah untuk dipengaruhi oleh hal-hal yang membuat ia akan terhilang dari Allah atau melakukan dosa (Henry dan Scott, 1979, p. 467). Dari arti nama, selama hidupnya, Yosia selalu ditopang dan didukung oleh Allah dalam segala sesuatu yang ia lakukan. Allah selalu mengarahkan ia menuju ke arah yang lebih benar dan ia tidak melakukan penyembahan berhala seperti yang dilakukan ayah dan kakeknya. Yosia mendedikasikan hidupnya dari ia kecil kepada Tuhan. la mempersiapkan dirinya untuk digunakan oleh Allah dalam masa pemerintahannya.

\section{Kepemimpinan Yosia (ay. 2-7)}

\section{Kepemimpinan yang Teosentris (ay. 2-3a)}

Kata theocentric berasal dari bahasa Yunani, theos berarti Tuhan dan centric berarti pusat. Theocentric adalah prinsip di mana dalam melakukan segala sesuatu hanya berpusat kepada Tuhan. Kepemimpinan teosentris berarti kepemimpinan yang berpusat kepada Tuhan (Zalukhu, 2017, p. 89). la hanya mengandalkan Tuhan dalam kepemimpinannya. Yosia dalam masa pemerintahannya juga berpusat kepada Tuhan. Hal ini dapat dilihat dari ia melakukan apa yang benar di mata Tuhan (ay. 2a), hidup seperti Daud dan tidak menyimpang ke kanan atau ke kiri (ay. 2b) dan mencari Allah (ay. 3a).

Yosia Melakukan Apa Yang Benar di Mata Tuhan (ay. 2a). Pernyataan yang pertama adalah Yosia melakukan apa yang benar di mata Tuhan (ay. 2a). Kata "apa yang benar" dalam teks Ibrani yaitu יָָָ yashar yang berarti "hidup jujur", "dianggap baik" atau "diterima baik" (Bibleworks 7, s.v. יָָָר). Dapat dikatakan bahwa selama Yosia hidup pada usianya yang masih muda, ia selalu hidup jujur dengan sepenuhnya dan dianggap baik oleh Tuhan.

Kata "apa yang benar" terdapat juga dalam kitab Ulangan 13:18, yaitu mendengarkan suara Tuhan dan berpegang teguh pada segala perintah-Nya. Maclaren mengatakann bahwa Yosia menyenangkan Tuhan. Hidup Yosia murni, bersih dan bermoral, bahkan bebas dari kejahatan yang terkadang menguasai diri seorang pangeran muda (Maclaren, n.d., p. 258). Tindakan Yosia dalam memerintah kerajaan itu juga berdasarkan kitab Taurat yang adalah perkataan Allah (Sweeney, 2001, 41). Dapat disimpulkan dari pendapat beberapa penafsir mengatakan bahwa 
Yosia menyenangkan hati Allah dengan hidup sesuai perkataan Allah yang adalah benar.

Dengan demikian, Yosia melakukan apa yang benar di mata Tuhan dengan menuruti segala perkataan-Nya. Kehidupan Yosia dinilai jujur, dianggap baik dan diterima dengan baik oleh Allah sendiri. Masa pemerintahannya hanya berdasarkan perkataan Tuhan yang adalah benar.

Yosia Hidup Seperti Daud dan Tidak Menyimpang ke Kanan atau ke Kiri (ay. 2b). Yosia melakukan apa yang benar di mata Tuhan, dengan menunjukkan bahwa ia hidup seperti Daud dan tidak menyimpang ke kanan atau ke kiri (ay. 2b). Kata "hidup" I. way-yelek adalah kata kerja imperfek orang ketiga tunggal maskulin dari kata dasar halak yang berarti "dia berjalan" atau "dia mengikuti" (Bibleworks 7, s.v. 仿). Artinya, kehidupan Daud selalu diikuti oleh Yosia.

Daud memiliki ketaatan kepada Allah yang patut untuk diteladani dan ia orang yang diurapi Allah juga. Alkitab banyak mengisahkan tentang penyertaan Tuhan terhadap kehidupan Daud (Tua, 2017, p. 75-84). Daud menunjukkan jati dirinya sebagai raja yang ditetapkan oleh Allah dengan bersungguh-sungguh hidup berkenan di hadirat-Nya. Hidup dengan pantas dan setia melakukan kehendak-Nya. Kesetiaan Daud kepada Allah yang membuat ia menjadi raja yang besar dan membuat bangsanya menjadi kuat. Daud juga menjadi raja yang disegani oleh rajaraja lainnya (Prasetya, 2006, p. 58). Dalam 1 Samuel 18:14 mengatakan, "Daud berhasil di segala perjalanannya, sebab TUHAN menyertai dia." Penyertaan Tuhan dibuktikan ketika pertama kali Daud mengalahkan raksasa Filistin (1 Sam. 17:45-47). Daud tidak mengandalkan kekuatan dan kemampuannya sendiri, tetapi mengandalkan kekuatan dan kuasa Allah. la mengaku di hadapan Goliat bahwa Allah yang berhak mengalahkan dan menyerahkan raksasa itu kepadanya (Prasetya, 2006, p. 57). Penyertaan Tuhan tidak hanya pada saat ia mengalahkan Goliat, tetapi dilihat dari kisah sebelumnya ketika ia diurapi menjadi raja Israel (1 Sam. 16:13). Sejak hari itu dan seterusnya berkuasalah Roh Tuhan atas Daud. la menjadi orang pilihan Allah (Prasetya, 2006, p. 57). Semakin lama semakin besarlah kuasa Daud karena Allah menyertainya (2 Sam 5:10). Daud hidup dengan mengikuti perintah Allah, melakukan kehendak-Nya dan bersandar penuh dengan kebenaran-Nya.

Dalam 2 Raja-raja 23:3 menjelaskan bahwa Yosia hidup dengan mengikuti Tuhan, dan tetap menuruti perintah-perintah-Nya dan segala ketetapan-ketetapanNya dengan segenap hati dan segenap jiwanya. Dalam 1 Raja-raja 14:8 juga menjelaskan bahwa Daud menaati segala perintah Tuhan dan mengikuti-Nya dengan segenap hatinya. Sebagai penekanan kepada Yerobeam bahwa Allah benci terhadap penyembahan berhala, la membandingkan bahwa Daud melakukan apa yang benar di mata-Nya, sedangkan Yerobeam tidak. Ini menunjukkan bahwa Yosia hidup seperti Daud dengan mengikuti teladan Daud yaitu taat kepada perintah Tuhan.

Selain hidup seperti Daud, Yosia juga tidak menyimpang ke kanan atau ke kiri.

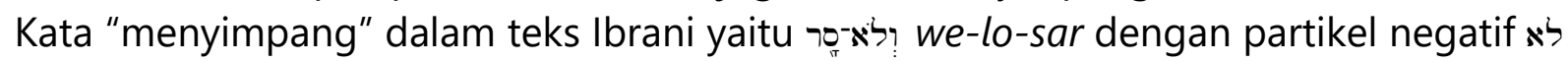
lo yang berarti "tidak" dan sar bentuk kata kerja perfek orang ketiga tunggal maskulin 
yang berarti "ia berbelok" (Bibleworks 7, s.v. וְלא-סר) Daud hidup dengan tidak menyembunyikan apapun kepada Allah. Langkah-langkahnya mengikuti jejak yang benar dan hatinya lurus dengan selalu mengoreksi diri di hadapan Tuhan (Wiersbe, 2014, p. 396). Jika dilihat dari awal mula terpecahnya kerajaan Israel (1 Raj. 12), Yerobeam menjadi orang yang berpengaruh dalam terpecahnya negeri itu. Kata "menyimpang" bisa dikatakan seperti yang dilakukan oleh Yerobeam. Yerobeam melakukan kejahatan lebih dari semua orang telah mendahuluinya dengan membuat patung-patung allah lain dan menyakiti hati Tuhan (1 Raj. 14:9). Allah menekankan bahwa Yerobeam tidak sama seperi hamba-Nya, Daud, yang tidak pernah menyimpang (1 Raj. 14:8). Yosia berjalan lurus mengikuti teladan Daud dan ia tidak berbelok ke kanan atau ke kiri dari teladan Daud tersebut.

Hidup seperti Daud menunjukkan bahwa Yosia meneladani kehidupan Daud di masa lalu dan tidak mengikuti ajaran yang lain. Situasi di Yehuda saat itu dipenuhi dengan kekejian penyembahan berhala tidak membuat Yosia terpengaruh untuk beribadah kepada ilah-ilah lain itu. Kehidupan Daud yang taat dan setia kepada Tuhan yang tidak menyimpang dengan menyembah allah-allah lain membuat ia selalu diberkati oleh Tuhan. Keberhasilan dan kemenangan yang selalu Daud peroleh dari peperangan yang ia pimpin membuktikan bahwa Allah selalu turut campur tangan dan memberkati Daud. Oleh sebab itu, Yosia tidak berbelok ke kanan atau ke kiri, tetapi berjalan lurus ke depan di jalan yang menurutnya baik untuknya, meskipun banyak hal yang menggoda dari samping kanan dan kiri yaitu tempat-tempat yang menyenangkan. Yosia tetap mengikuti teladan Daud (Maclaren, n.d., p. 258). Hidup seperti Daud dan tidak menyimpang ke kanan atau ke kiri menjadi pedoman bagi Yosia sebagai raja Yehuda.

Yosia Mencari Allah (ay. 3a). Selain Yosia melakukan apa yang benar di mata Allah, hidup seperti Daud dan tidak menyimpang ke kanan dan ke kiri, disebutkan bahwa Yosia adalah pemimpin yang takut akan Tuhan yaitu karena Yosia mencari Allah pada (ay. 3a). Kata "Mencari" לִדְרוֹש lid-ro-wos dari kata dasar הרש darash yang berarti "meminta petunjuk" (Bibleworks 7, s.v. דרש (דשר). Itu menunjukkan bahwa Yosia bukan hanya sekadar mencari tetapi meminta petunjuk dari Allah yang Daud sembah.

Kata "meminta petunjuk" juga terdapat dalam 2 Tawarikh 34:21 yang mana dijelaskan tentang Yosia meminta petunjuk Tuhan ketika ia mendengar tentang perkataan Taurat yang telah ditemukan tersebut. la meminta petunjuk apa maksud dari perkataan Tuhan yang mana murkanya masih sangat hangat terhadap Yehuda. "Meminta petunjuk" terdapat juga di ayat 26, di mana nabiah Hulda mengatakan bahwa Allah berfirman kepadanya bahwa akan ada raja Yehuda yang akan meminta petunjuk Tuhan kepadanya. Yosia mencari atau meminta petunjuk Allah agar ia mengetahui apa tujuan Tuhan baginya.

Maclaren mengatakan pada usia yang keenam belas tahun, awal dari kedewasaan Yosia ialah ia terbangun untuk memiliki pengalaman yang lebih dalam dan merasakan sentuhan Tuhan lebih dekat. Yosia akan mengalami kehidupan yang keras tetapi ia meminta visi yang jelas dari Allah (Maclaren, n.d., p. 258-259). 
Pemikiran yang sama juga dimiliki oleh Bakker yang mengatakan bahwa ketika Yosia dewasa dan dapat memerintah sendiri pada tahun kedelapan pemerintahannya, ia bertingkah laku seperti Daud dan taat kepada Allah Daud (Bakker, 2004, p. 672). Tidak diberitahukan siapa yang memberitahu ia tentang Allah. Tetapi nabi yang melayani pada saat itu ketika masa pemerintahan Yosia adalah nabi Yeremia (Yer. 1:2). Ada kemungkinan dari pelayanan nabi Yeremia, Yosia mengetahui sedikit tentang Allah Daud. Seperti Daud selalu meminta petunjuk kepada Allah, begitu juga dengan Yosia meminta petunjuk kepada Allah tentang apa yang akan ia lakukan dalam pemerintahannya.

Yosia termasuk raja yang paling baik, yang pernah memerintah atas Yehuda. Apa yang pernah dikatakan tentang Hizkia (2 Taw. 29:2) juga berlaku untuk Yosia. la menuruti segala tingkah laku raja Daud, moyangnya (Bakker, 2004, p. 672). Daud mengatakan dalam doanya bahwa takut akan Tuhan adalah selalu minta petunjuk Tuhan dan hidup menurut kebenaran-Nya (Maz. 86:11). Daud juga mengatakan bahwa orang yang takut akan Tuhan akan menunjukkan jalan yang benar dan mengetahui perjanjian-Nya (Maz. 25:12,14).

Dengan demikian, Yosia dalam kepemimpinannya berpusat kepada Tuhan. la menaati dan melakukan perkataan Allah melalui firman-Nya sebagai dasar dalam menjalankan kepemimpinannya dan meminta petunjuk Tuhan melalui firman Tuhan tersebut. la mencari Tuhan untuk bersiap diri dipergunakan oleh Tuhan dalam rencana-Nya ketika semua orang atau yang seusia dengannya sibuk mencari hal-hal yang merusak diri atau berdosa.

\section{Kepemimpinan yang Melakukan Pentahiran (ay. 3b-7)}

Diusia Yosia yang muda, ia sudah mulai bertindak dalam kepemimpinannya. la melakukan pentahiran Yehuda dan Yerusalem dari penyembahan berhala (ay. 3b). Yosia dalam pemerintahannya terlihat sangat berbeda dari pemerintahan ayahnya, Amon, dan kakeknya Manasye. Pada masa pemerintahan ayah dan kakeknya banyak menumpahkan darah orang yang tidak berdosa dan mengembangkan penyembahan berhala yang keji, tetapi Yosia tidak demikian (Free, 2001, p. 275). Yosia melakukan pentahiran terhadap Yehuda.

Kata "pentahiran" dari kata dasar "tahir" yang berarti bersih, suci, murni (Kamus Besar Bahasa Indonesia (KBBI) Online). Dalam teks ibrani "mentahirkan" לטֵ le-ta-her dari kata dasar טָּ taher yang berarti "untuk membersihkan, memurnikan secara fisik, secara seremonial, secara moral" (Bibleworks 7, s.v. טָָָ). Tujuan pentahiran adalah untuk membuat bersih atau membuat murni. la membersihkan rumah TUHAN secara besar-besaran dari penyembahan berhala tersebut. la bahkan memecat para penyembah berhala dari seluruh negeri itu dan menajiskan tempat-tempat penyembahan berhala tersebut sehingga tidak ada lagi orang-orang yang berani mendekati tempat itu (Lasor, Hubbard, dan Bush, 2008, p. 399). Yosia menghancurkan fisik dari penyembahan berhala tersebut, yaitu patung-patung, tiang-tiang, dsb. la juga menghancurkan cara peribadatannya dan ajaran dari berhala tersebut. Itu 
menunjukkan bahwa Yosia tidak menginginkan ada sesuatu hal yang tersisa dari penyembahan berhala tersebut.

Tahir juga memberi arti yaitu penghindaran dari pencemaran ritual. Sangat penting bagi orang Ibrani untuk ketahiran itu, karena ketidaktahiran menjadi penghalang dalam kegiatan keagamaan. Penyebab ketidaktahiran itu karena adanya persentuhan dengan yang mati, dengan segala hal yang dilarang serta dengan berbagai penyakit (Browning, 2007, p. 433). Dengan penyembahan berhala, rakyat Yehuda menjadi keji dan najis di hadapan Allah. Yosia menganggap penyembahan berhala itu adalah penyakit dan akan mencemarkan ritual atau kegiatan keagamaan kepada Allah. Oleh sebab itu, ia melakukan pentahiran tersebut agar nama Allah tidak dicemarkan oleh ilah-ilah tersebut. Adapun tindakan-tindakan yang dilakukan dalam ayat 4-7, yaitu penghancuran mezbah-mezbah para Baal (ay. 4), membakar tulangtulang para imam (ay. 5) dan bahkan juga ia melakukan pentahiran sampai di daerah Israel (ay. 6-7).

\section{Penghancuran Mezbah-mezbah Para Baal (ay. 4)}

Dalam ayat 4, Yosia melakukan penghancuran terhadap penyembahan berhala tersebut. Kata "dirobohkan" נתץ naw-thats dari kata kerja imperfek orang ketiga jamak maskulin yang berarti "merobohkan, menghancurkan". Objeknya berbentuk

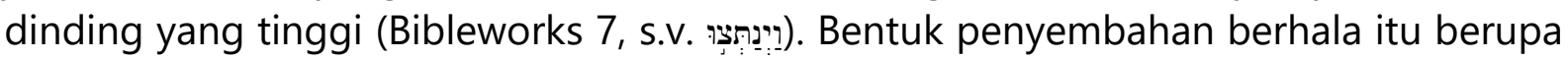
mezbah-mezbah para Baal (2 Taw. 34:4). Kata "tiang-tiang berhala" dalam teks Ibrani yaitu אשָרָה ash-ay-raw artinya "dewi Ashera" atau "ibu para dewa." Dalam kamus Alkitab, Baal artinya tuan, kemudian gelar dewa-dewa penduduk asli tanah Kanaan yang ditentang para nabi Tuhan dalam Perjanjian Lama. Ciri khasnya ialah menjamin kesuburan. Karena itu Baal seringkali turut disembah orang Israel sendiri. Asyera adalah dewi penduduk asli tanah Kanaan yang menjamin kesuburan. Dipuja sebagai isteri Baal (Kamus Alkitab Lembaga Alitab Indonesia, 2009, p. 621-622).

Dapat digambarkan bentuk penyembahan berhala tersebut bangunan yang tinggi dengan tiang dan pilar-pilar yang banyak. Karena cara Yosia menghancurkannya diawali dengan merobohkan yang artinya menyamaratakan sesuatu yang ada di atas dengan yang di bawah. Pedupaan-pedupaan lainnya yang berupa gambar, simbol, serta sesuatu yang sangat dikagumi menjadi peralatan bangsa Israel untuk melakukan penyembahan berhala tersebut. Yosia menghancurkan segala macam bentuk fisik berhala tersebut.

\section{Membakar Tulang-Tulang Para Imam (ay. 5)}

Yosia melakukan pembakaran terhadap tulang-tulang para imam. Kata "membakar" dalam teks Ibrani yaitu שָָָׁ saw-raf dengan kata kerja perfek orang ketiga tunggal maskulin yang berarti "ia membakarnya sampai habis." Para imam yang dimaksud adalah orang-orang atau pelayan-pelayan Allah yang sebenarnya terlibat dalam penyimpangan dengan menyembah berhala (Bibleworks 7, s.v. שָָרָר). Yosia menghukum para imam tersebut dengan membakar tulang-tulangnya. Dengan 
menghamburkan debu di kuburan para penyembah berhala, Yosia seolah-olah berkata tidak ada yang bisa membantu berhala itu untuk berdiri lagi karena telah dihancurkannya dan rata dengan tanah (Maclaren, n.d., p. 259). Ketika para imam itu mati, tulang-tulangnya dipakai oleh para penyembah berhala lainnya untuk dipersembahkan dan juga dijadikan sebagai berhala. Yosia membakar habis semua tulang-tulang tersebut hingga menjadi debu di atas mezbah-mezbah tersebut. Bentuk upacara dan ajaran moral dengan menyembah tulang-tulang para imam dihanguskan dan dilenyapkan oleh Yosia.

\section{Penghancuran Berhala di Luar Daerah Yehuda (ay. 6-7)}

Yosia tidak hanya menghancurkan berhala yang ada di daerah kekuasaannya, seperti Yehuda dan Yerusalem. Tetapi ia juga menghancurkan berhala yang ada di daerah Israel, seperti Manasye, Efraim, Simeon sampai ke Naftali (ayat 6). "Juga di kota-kota" וּבְעָרֵ ata uvea'er dengan kata benda feminim jamak yang berarti "kota-

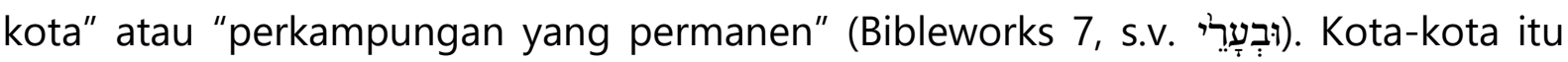
berada di daerah Israel bagian utara yang telah mengalami kehancuran dan reruntuhan.

Yosia ingin memperluas jangkauan reformasinya. Apalagi penyerangan yang terjadi kepada Asyur tidak bisa menghalangi penyebaran pentahiran yang dilakukan oleh Yosia (Carson, ed., 1994, p. 417). Raja Babel yang pada waktu itu memerangi Asyur ternyata menolong Yosia terbebas dari kekuasaan Asyur. Babel memukul kalah dan membuat Asyur menyerah kepada orang-orang Babel. Hal ini yang mengakibatkan Asyur tidak sempat lagi mengurus daerah-daerah jajahannya (Bakker, 2004, p. 672).

Dalam terjemahan BIS mengatakan, "Hal yang sama dilakukannya juga di kotakota dan di daerah-daerah yang telah hancur di wilayah Manasye, Efraim, dan Simeon, sampai ke Naftali di utara." Yosia tidak membatasi tindakannya pada Yehuda saja, tetapi berkelana ke Kerajaan Utara yang lama, dengan prinsip bahwa Efraim juga bagian dari Israel (Goldingay, 2012, p. 189). Yosia pergi ke daerah Israel bekas daerah kesepuluh suku itu dan merusakkan semua bukit pengorbanan di sana. la memiliki cukup kekuasaan untuk menghancurkan mezbah-mezbah serta berhala-berhala sampai ke daerah suku Naftali yang diam di sebelah utara (34:6; Bakker, 2004, p. 673). Seperti halnya dalam 2 Raja-raja 23:15-20, Yosia melakukan pentahiran itu sampai di Betel dan Samaria. Yosia menghancurkan semuanya serta menghamburkannya di atas kuburan orang-orang yang melakukan penyembahan tersebut. Segala sesuatu yang berkaitan dengan berhala itu dihancurkan oleh Yosia dengan keberanian yang ia miliki.

Tindakan drastis pemerintahan Yosia diambil untuk melakukan reformasi menyeluruh terhadap penyembahan berhala dan secara bersamaan untuk menyatukan orang-orang Yehuda dan Israel dalam penyembahan kepada Allah (Buttrick, 1952, p. 537). Seperti Yosia menemukan orang-orang di Kerajaan Utara lama yang ingin melibatkan diri dengan bait suci di Yerusalem (Goldingay, 2012, p. 
190). Bahkan orang-orang yang berada di bawah pemerintahan raja Israel memperbolehkan berhala-berhala dan tempat-tempat penyembahan berhala untuk dihancurkan (Clarke, ed., 1977, p. 702). Pentahiran yang dilakukan Yosia membuat semua sistem peribadatan kembali kepada yang benar. Diadakannya kembali perayaan paskah pada tahun kedelapan belas pemerintahannya, sejak berhentinya perayaan paskah dari zaman para hakim yang memerintah atas Israel (2 Raj. 23:2223).

Dengan demikian, Yosia walaupun muda berhasil dalam kepemimpinannya. Keberhasilannya dalam memimpin karena prinsip kepemimpinannya yang berpusat kepada Tuhan, menjalankan apa yang Tuhan inginkan yaitu melenyapkan segala berhala atau sesuatu yang telah menduakan Tuhan. Yosia juga tuntas dalam menyelesaikan tugasnya. Karena dalam mentahirkan berhala tersebut, tidak ada yang luput dari pandangannya. la melenyapkan segala sesuatu yang berhubungan dengan berhala tersebut, baik itu bentuk fisiknya, orang-orang yang terlibat, upacara serta moralnya, sampai kepada daerah-daerah utara yang jauh dari wilayah pemerintahannya. Yang mana daerah tersebut telah diterlantarkan akibat malapetaka yang telah Allah kirimkan karena berhala yang menyakiti hati Tuhan. Sehingga tidak ada lagi yang sisa, dan semua umat-Nya kembali menyembah-Nya.

\section{Implikasi dari Kepemimpinan Yosia bagi Kepemimpinan Pemuda di Gereja}

Kepemimpinan Yosia dapat diimplikasikan bagi kepemimpinan pemuda di gereja. Dalam bab ini, penulis akan menjelaskan implikasi dari kepemimpinan Yosia bagi kepemimpinan pemuda di gereja dengan menarik hal-hal penting dari hasil analisis pada bab tiga untuk menunjukkan pelaksanaan dan penerapannya.

\section{Tuhan Bisa Memakai Anak Muda Untuk Menjadi Pemimpin (2 Taw. 34:1)}

Yosia dilahirkan dalam konteks ketidaksetiaan di Yehuda yaitu penyembahan kepada allah-allah lain (Baal). Namun, dalam teks 2 Taw. 34:1-7 memberitahukan bahwa ia sudah berpaling kepada Allahnya Yehuda (Goldingay, 2012, p. 189). Yehuda pada saat itu berada di dalam perbudakan dosa yaitu penyembahan kepada berhala yang menjadi kekejian di mata Allah. Tetapi ketika Yosia memerintah atas Yehuda, ia tidak melakukan penyembahan berhala tersebut. Walaupun Yosia lahir di tengahtengah orang yang rusak karena dosa menyembah berhala, tetapi selama Yosia hidup tidak pernah melakukan berhala tersebut. Hal ini dikarenakan keberadaan Yosia sebagai raja yang sangat muda telah ditetapkan dan dipilih oleh Allah melalui nubuatan abdi Allah (1 Raj. 13:2).

Walaupun Yosia muda, tetapi ia tidak pernah merasa kurang percaya diri dan menyerah untuk memimpin Yehuda. Tetapi ia lebih bersemangat dalam pemerintahannya karena tindakannya dalam pentahiran. Karena ia mengetahui bahwa Allah selalu mendukung dan menopang dalam setiap apa yang akan ia lakukan untuk Allah. Yosia, seorang yang muda mendedikasikan hidupnya untuk Tuhan. Kaum muda yang terlibat dalam kepemimpinan di gereja juga harus 
mendedikasikan hidupnya hanya untuk Tuhan. Meyakini bahwa Tuhan sudah memilih untuk memimpin dan mengerjakan tugas-Nya.

Anak-anak muda yang percaya kepada Kristus harus bangkit dan mulai bertumbuh guna memimpin generasinya bahkan gereja. Anak muda Kristen harus menyadari bahwa ia harus menjadi garam dan terang bagi dunia (Mat. 5:13-16) dengan menunjukkan bahwa Yesus ada di dalam diri anak muda dan dengan semangat menunjukkan jiwa kepemimpinan dalam setiap kegiatan yang diikuti. Serta menyadari bahwa Allah yang memanggil untuk menjadi pemimpin (Maxwell, 2014, p. 1).

Dalam Alkitab juga banyak terdapat anak muda yang Tuhan pilih dan pakai untuk menjadi pemimpin, seperti Musa (Kel. 3:10), Yosua (Yos. 1:1-3), Daud (1 Sam. 16:12-13). Dalam Yeremia 1:5-7 juga menuliskan bahwa Allah sudah mengenal dan menetapkan Yeremia sebagai nabi bagi bangsa-bangsa. Walaupun Yeremia merasa bahwa ia masih muda, tetapi Allah mengatakan bahwa kepada siapa saja la utus maka la akan menyertai. Begitu juga dengan anak-anak muda di gereja, yakini bahwa Allah telah memilih untuk menjadi pemimpin yang benar dan Allah akan terus menyertai sampai ke arah yang benar. Tuhan bisa memakai siapa saja untuk menjadi pemimpin, bahkan anak muda pun yang sering Tuhan pakai.

Di era milenial ini, pemuda juga dapat mengembangkan karakternya dan memanfaatkan situasi. Pemuda, yang bertumbuh dan lahir pada zaman milenial memiliki nilai yang penting dalam gereja juga. Peramesti dan Kusmana memberikan pandangan yang praktis untuk mewujudkan kepemimpinan yang ideal dalam kepemimpinan era milenial. Hal ini dapat diaplikasikan bagi pemuda dalam memimpin juga. Digital Mindset, memanfaatkan dengan sebaik mungkin teknologi yang saat ini sedang berkembang. Observer dan Active Listener, seorang pengamat keadaan dan pendengar yang baik. Agile, cerdas dalam mengambil peluang. Inclusive, memahami masalah dalam pemikiran seseorang, dikarenakan tentangan rumitnya dan banyaknya pemikiran dan pandangan orang saat ini. Brave to be different, mengambil keputusan untuk mengambil nilai yang berbeda asalkan masih di bawah otoritas firman Tuhan. Unbeatable, pantang mundur serta berjuang terus dalam memimpin (Peramesti dan Kusmana, 2018, p. 79-80).

\section{Kepemimpinan Yang Berpusat Kepada Tuhan (2 Taw. 34:2-3a)}

Dalam kepemimpinan Yosia yang berpusat kepada Tuhan, pelaksanaannya ia melakukan apa yang benar di mata Tuhan (34:2a), hidup seperti Daud dan tidak menyimpang ke kanan atau ke kiri (34:2b), dan mencari Allah (34:3a). Kepemimpinan yang berpusat kepada Tuhan seharusnya menjadi bagian yang paling penting dalam kepemimpinan di gereja khususnya bagi pemuda saat ini dengan menaati dan melakukan Firman Tuhan dan setia dalam meminta petunjuk Tuhan dengan berdoa. 


\section{Memiliki Kehidupan Yang Kudus}

Yosia menunjukkan melakukan apa yang benar di mata Tuhan dengan melakukan apa yang menyenangkan hati Tuhan. Segala sesuatu yang dilakukan oleh Yosia, dianggap baik oleh Tuhan dan itu menyenangkan hati-Nya (34:2a). Dalam terjemahan Bahasa Indonesia Sehari-hari (BIS), ayat 2a mengatakan, "la melakukan yang menyenangkan hati Tuhan." Hidup sesuai dengan apa yang Allah kehendaki akan menunjukkan bahwa hidup itu menyenangkan hati-Nya.

Apa yang benar di mata Tuhan atau hidup menyenangkan hati-Nya adalah manusia terus hidup memuliakan nama-Nya dan terbebas dari perbudakan dosa (Strauss, 2011, p. 99). Terbebas dari perbudakan dosa adalah manusia telah diselamatkan dengan perjuangan Yesus untuk mengubah cara berpikir manusia tentang dosa dan keselamatan. Kematian Yesus di kayu salib mengubah nasib manusia yang malang karena dosa menjadi istimewa karena darah-Nya (Surbakti, 2006, p. 76). Pola pikir berubah. Yesus menjadi fokus dan yang diandalkan untuk keselamatan. Dalam Ibrani 10:10 mengatakan bahwa kematian Yesus di kayu salib telah menguduskan seluruh manusia dari dosa dengan satu kali untuk selamalamanya.

Hidup kudus berarti hidup dengan tidak bercacat dan tidak bernoda di tengahtengah dunia yang fasik ini. Hidup yang dipisahkan dari jahatnya dunia (Gunawan, 2014, p. 269). Seorang pemimpin yang berpusat pada Tuhan harus memiliki hidup yang kudus atau hidup dalam kekudusan. Hidup pemimpin harus terpisah dari kefasikan dunia ketika ia hidup dalam Kristus. Dalam Kolose 3:5 mengatakan bahwa ketika Kristus sudah ada dalam diri manusia, maka manusia harus mematikan segala sesuatu yang duniawi, yaitu percabulan, kenajisan, hawa nafsu, nafsu jahat, dan keserakahan yang sama dengan penyembahan berhala. Dengan demikian, seorang anak muda yang memimpin harus hidup dalam kekudusan, yaitu tidak mengikuti dunia yang penuh dengan kejahatan.

\section{Hidup Dengan Jujur}

Yosia hidup seperti Daud dan tidak menyimpang ke kanan atau ke kiri (2 Taw. 34:2). Daud hidup selalu setia dan pantas melakukan kehendak-Nya. Kelayakannya dalam melakukan kehendak Tuhan adalah dengan tidak hidup dalam dosa. Daud dikatakan bahwa ia tidak menyimpang dari jalan pendahulunya yang terkenal atau tidak menyimpang ke kanan atau ke kiri (Eynikel, 1996, p. 117). Banyak para pendahulu yang juga mengikuti jejak Daud. Sikap Daud dalam masa pemerintahannya dan sebelum ia jatuh ke dalam dosa, Daud hidup takut akan Allah dan hidup dengan jujur (Park, 2018, bagian 11). Daud hidup dengan setia terhadap apa yang dikatakan oleh Allah melalui firman-Nya dan tidak menyimpang dari firman Allah, maka keberhasilan dan berkat selalu diterima oleh Daud. Hal inilah yang menjadikan Yosia hidup seperti Daud (2 Taw. 34:2b).

Daud dikatakan hidup dengan jujur, karena sikapnya yang selalu bertanya kepada Tuhan dengan hati yang tulus (Maz. 13:2-3) dan selalu mengakui 
kesalahannya di hadapan Tuhan (Maz. 17:3). Yosia dengan hidup seperti Daud dan tidak menyimpang ke kanan atau ke kiri berarti Yosia selalu hidup dengan jujur di hadapan Tuhan dan selalu memiliki hati yang lurus serta berjalan di arah yang benar. Ketika ia melakukan kesalahan ataupun ia mengalami kesulitan dalam masa pemerintahannya, Yosia akan bertanya kepada Tuhan dengan hati yang tulus dan mengakui serta mengoreksi kesalahan di dalam dirinya.

1 Yohanes 1:9 mencatatkan seorang yang percaya mengaku dosa kepada Allah. Manusia yang mengakui dosanya, maka ia berupaya hidup jujur di hadapan Tuhan. Jika seorang pemimpin muda mengaku bahwa ia berdosa, maka ia sedang hidup jujur di hadapan Tuhan. Dalam Kolose 4:1, mengatakan bahwa setiap pemimpin harus berlaku jujur dan adil kepada setiap anggotanya karena ia juga mempunyai pemimpin yang ada di sorga, yaitu Mesias (Mat. 23:10). Jika seorang pemimpin hidup dengan jujur, memiliki sikap yang jujur, maka kepercayaan dari setiap anggota akan ia terima. Dengan demikian, seorang pemimpin harus hidup dengan jujur di hadapan Tuhan sehingga ia mampu bersikap jujur kepada anggotanya atau orang-orang yang ia pimpin.

\section{Hidup Mencari Perkenanan Tuhan}

Pada usianya yang masih remaja dan dalam masa pemerintahannya, Yosia mencari Allah (34:3a). Mencari dalam arti yaitu meminta petunjuk Tuhan. Sebagai pemimpin, meminta petunjuk Tuhan adalah hal yang paling utama yang dibutuhkan mengingat pikiran adalah medan terhadap perjuangan dalam mengambil keputusan. Dari sanalah para pemimpin akan bergumul untuk sesuatu yang menguntungkan atau tidak dari dua arah yang dipikirkan dengan mempertimbangkan konsekuensi yang akan dihadapi yang akhirnya akan menentukan pilihan-pilihan itu (Strauss, 2011, p. 139). Hal serupa dialami oleh Yosia dalam masa pemerintahannya, apalagi dengan usianya yang masih muda belia (34:3a).

Yosia tidak pernah mengabaikan apa yang diketahuinya sebagai tugasnya untuk Allah dan kerajaannya (Clarke, ed., 1977, p. 702). Seperti ketika Yosia mendengar perkataan Kitab Taurat dari nabiah Hulda (2 Taw. 34:22), Yosia mengetahui bahwa penyembahan berhala yang telah ada itu telah menyakiti hati Allah dan umat-Nya banyak yang meninggalkan-Nya. Karena itu, Allah hendak mengirimkan malapetaka dan ingin melenyapkan segala berhala dan orang-orang yang terlibat tersebut. Setelah mendengar hal itu, Yosia berusaha agar berhala-berhala itu dihancurkan dan semua orang kembali menyembah Allah (2 Taw. 34:31). Yosia hidup dengan layak melakukan apa yang Tuhan inginkan karena ia tidak hidup dalam dosa menyembah berhala itu.

Dosa akan mengakibatkan kekalahan atau ketidakberhasilan jika pemimpinnya tidak menaati firman Tuhan (Wiersbe, 2014, p. 170). Stevri Indra Lumintang dalam bukunya yang berjudul Theologia Kepemimpinan Kristen mengatakan bahwa kata "berhasil" selalu ada hubungannya dengan penyertaan Tuhan yang membuat seseorang berhasil dalam menjalankan tugasnya yang sesuai dengan kehendak 
Tuhan (Lumintang, 2015, p. 43). Keadaan ini juga dibenarkan oleh David Hocking yang mengatakan bahwa "keberhasilan menurut Allah berdasarkan pada ketaatan tanpa kompromi kepada firman-Nya" (Hocking, 1993, p. 5). Hengki Wijaya mengatakan bahwa munculnya hubungan yang baik manusia dengan Allah dari ketaatannya kepada Allah sendiri. Keberhasilan seorang pemimpin ditentukan dari eratnya hubungan pemimpin itu dengan Tuhan (Wijaya, 2015). Hubungan yang baik dengan Tuhan sangat memengaruhi keberhasilan dalam suatu kepemimpinan. Seorang pemimpin seharusnya mengejar perkenanan Tuhan dan keakraban hubungan dengan Tuhan, bukan dari manusia. Yang dikejar adalah pujian dari Allah, bukan uang dan pujian dari manusia. Seperti yang disinggung oleh Yahya Wijaya, model kepemimpinan Yesus menekankan hubungan kedekatan dengan Bapa-Nya (Wijaya, 2018, p. 129).

Sebagai kesimpulan, hidup yang berpusat pada Tuhan yaitu, hidup di dalam kekudusan, memiliki kehidupan yang jujur dengan ketulusan hati mengakui dosa, dan hidup berkenan kepada-Nya dengan menaati dan melakukan firman Tuhan yang akan membuat segala sesuatu yang dilakukan memperoleh keberhasilan.

\section{Kepemimpinan Yang Siap Menghadapi Tantangan (2 Taw. 34:3b-5)}

"Seorang pemimpin tidak dilahirkan, tetapi dibentuk," ungkap Zaluchu (Zaluchu, 2018, p. 145). Demikian pembentukan ini juga biasanya dikaitkan dengan tantangan. Hal ini juga yang dialami Yosia dalam kepemimpinannya. Tantangan yang dihadapi oleh Yosia ialah adanya penyembahan berhala dalam wilayah kekuasaannya dan hal itu adalah keji di mata Allah. Tantangan itu dihadapi dan diatasinya dengan melakukan pentahiran terhadap berhala tersebut. Yosia melaksanakan tugasnya. Pentahirannya tidak setengah-setengah dilakukannya. la menghancurkan berhala itu mulai dari fisiknya sampai kepada upacara dan moralnya (2 Taw. 34:3b-5), bahkan sampai ke daerah bagian utara. Yosia dengan semangat dan keberanian yang dimiliki melakukan tugasnya dengan maksimal. Tindakan-tindakannya dalam melakukan pentahiran tersebut menunjukkan bahwa ia sangat tidak suka dengan kekejian di mata Allah tersebut.

Dalam gereja juga terdapat tantangan, tidak hanya dari luar. Bahkan tantangan dalam gereja sangat sulit untuk diatasi dan dihadapi karena orang-orang yang ada dalam gereja sudah mendengar tentang kebenaran, sehingga kemampuan untuk memanipulasi firman Tuhan atau menggunakan firman Tuhan untuk menipu demi kepentingan sendiri sangat halus dan hampir tidak kelihatan. Tantangan yang biasa terjadi di gereja adalah adanya berhala teknologi bagi kaum muda dan keegoisan para petinggi gereja yang menyebabkan gereja-gereja lebih mementingkan diri sendiri dan menduakan Tuhan.

\section{Berhala Teknologi Bagi Kaum Muda}

Yosia membersihkan segala macam bentuk penyembahan berhala atau mezbah-mezbah Baal yang ada di wilayan kekuasaannya, yaitu Yehuda dan 
Yerusalem (2 Taw. 34:4). Tindakan menyembah Baal karena keserakahannya untuk memiliki sesuatu yang lebih. Menduakan Tuhan atau mementingkan hal-hal yang duniawi dari pada Tuhan disebut sebagai tindakan dalam berhala. Banyak gereja khususnya kaum muda juga lebih mementingkan hal-hal yang duniawi dari pada Tuhan seperti, kecanggihan teknologi, dunia pekerjaan, materialistik dan sebagainya.

Dunia saat ini, telah dipenuhi dengan berbagai kecanggihan teknologi seperti, komputer, internet, media sosial, telepon genggam (smartphone). Dilakukan penelitian oleh para teoritis, analis dan moralis yang mengatakan bahwa perkembangan teknologi mengakibatkan terjadinya fenomena kemerosotan anak muda yang mana anak-anak muda dibuat mabuk oleh teknologi. Anak muda terhanyut dengan dunia fantasi yang ada dalam kecanggihan teknologi tersebut seperti, games, gaya hidup hedonisme yang selalu terlihat dalam media sosial, dan terjadinya kemerosotan moral terhadap anak-anak muda akibat penyebaran hoaks (Sitompul, 2017, p. 1-16). Situasi ini juga terjadi dalam gereja yang mana anak-anak mudanya lebih mementingkan kecanggihan teknologi dari pada keseriusan beribadah kepada Tuhan. Ketika beribadah, anak-anak muda ini sering bermain smartphone, membuka media sosial dari pada membuka Alkitab dan mendengarkan firman Tuhan. Adanya berita hoaks, ujaran kebencian dan caci maki yang selalu dilihat oleh anak-anak muda itu memengaruhi sikap hidupnya yang mengakibatkan beberapa anak-anak muda dalam gereja sekarang kehilangan nilai-nilai kristiani atau nilai-nilai alkitabiah. Kaum muda ini tidak lagi memerhatikan keterlibatan Yesus Kristus dan kasih-Nya dalam hidupnya karena kenikmatan yang dunia berikan melalui kecanggihan teknologi tersebut. Anak-anak muda ini tidak bisa melepaskan kecanggihan teknologi ketika datang kepada Tuhan, lebih mengutamakan gadget dari pada firman Tuhan dan berdoa.

Tidak hanya kecanggihan teknologi yang mengakibatkan anak-anak muda kehilangan nilai-nilai kristiani dalam hidupnya. Tetapi banyak juga kaum muda Kristen yang setelah menikah tak lagi aktif karena ia hanya mengejar karir, uang, kendaraan, klub dan rumah (Mandryk, 2013, p. 1040). Kesibukannya dalam pekerjaan untuk mendapatkan sesuatu yang diinginkan seringkali membuat kaum muda ini melupakan Tuhan. Ketika ada persekutuan rohani atau kegiatan ibadah di hari minggu, banyak anak-anak muda ini tidak menyempatkan waktunya untuk beribadah kepada Tuhan tetapi lebih memilih sibuk lembur dengan pekerjaan. Kurangnya interaksi seorang anak muda kepada Tuhan akan mengakibatkan kerohanian anak muda tersebut menjadi sakit atau merosot. Potensinya untuk terlibat dalam pelayanan di gereja menjadi tidak baik karena nilai-nilai alkitabiahnya telah hilang dikarenakan nilai-nilai yang ia dapatkan dari penggunaan teknologi yang berlebihan dan tidak memiliki waktu dengan Tuhan karena pekerjaan.

Oleh sebab itu, seorang pemimpin muda harus bijaksana dalam penggunaan teknologi. Teknologi bagaikan 2 sisi mata uang, yang punya sisi baik dan sisi buruk. Kelebihan penggunaan akan snagat berbahaya dan mengikat pemuda; membawa hubungan yang jauh dengan Allah. Namun, jika dengan bijaksana serta dipergunakan 
untuk pertumbuhan rohani dan pembelajaran iman, teknologi akan sangat bermanfaat. Perlu kebijaksanaan dalam pemanfaatan teknologi.

\section{Keegoisan Para Petinggi Gereja Kepada Kaum Muda}

Yosia tidak hanya menghancurkan bentuk fisik dari berhala itu, tetapi segala sesuatu yang berkaitan dengan penyembahan berhala sampai kepada pemecatan para pelayan yang melayani di bukit-bukit pengorbanan tersebut (Tobing dan Yosia, 2017, p. 12). Dalam 2 Tawarikh 34:5 kita melihat Yosia membakar tulang-tulang imam-imam yang kemungkinan besar terlibat dalam penyembahan berhala. Yosia melihat hal yang menjijikkan terjadi di wilayah kekuasaannya dan ia juga mengetahui bahwa hal itu keji di mata Allah.

Gereja juga tidak luput dari yang namanya kekuasaan. Gereja memiliki para petinggi-petinggi untuk melindungi otoritas gerejanya. Tetapi tidak kurang juga para petinggi tersebut egois karena kekuasaan yang ia miliki. Para petinggi itu termasuk, majelis, BPJ, bahkan gembala atau pendeta senior yang kadang memiliki sisi negatif karena kepentingan diri sendiri. Rasa iri yang dimiliki oleh gembala atau pendeta senior terhadap pemimpin muda atau gembala muda akan menimbulkan tindakan yang berusaha menjatuhkan junior tersebut (Tacoy, 2009, p. 37-38). Memang terdapat permasalahan juga dalam kehidupan pemuda seperti kekecewaan dengan gereja atau orang-orang di dalamnya, ketertarikan dengan hal duniawi lebih dari rohani, dan masalah pemuda lain. Namun, tidak dapat dipungkiri dan berkaitan dengan konteks poin ini juga, kekuasaan seringkali menciptakan permasalahan dalam gereja. Ambisi dari para penguasa gereja atau para petinggi gereja inilah yang biasanya tidak bisa memberi kesempatan kepada anak-anak muda untuk terlibat dalam pelayanan di gereja. Ketika kaum muda dianggap lebih baik oleh jemaat untuk memimpin sesuatu, ada timbul rasa iri hati pada kaum tua atau senior. Kejujuran yang dimiliki oleh kaum muda ketika melakukan tugasnya dalam gereja, akan dikatakan sebagai ancaman bagi para petinggi gereja yang berlaku curang dalam jabatannya.

Rasul Paulus mengatakan kepada Timotius tentang keadaan manusia pada akhir zaman, yaitu manusia akan mencintai diri sendiri, hamba uang, pembual, menyombongkan diri, pemfitnah, menjelekkan orang lain dan tidak mau adanya kedamaian, dan lebih menuruti hawa nafsu dari pada menuruti Allah (2 Tim. 3:1-5). Hal ini sangat jelas mengatakan bahwa gereja juga mengalami keegoisan dari para petinggi gereja demi keinginannya pribadi. Paulus mengatakan kepada Timotius, walaupun banyak orang yang menganggap Timotius rendah tetapi ia harus bisa menjadi teladan bagi orang-orang percaya, dalam perkataan, tingkah laku, kasih, kesetiaan dan kesucian (1 Tim. 4:12). Seorang pemimpin muda tidak harus malu dalam memberitakan perkataan kebenaran yang sudah diketahui (2 Tim. 2:15). Kaum muda harus menghindari nafsu-nafsu orang muda dan hanya mengejar keadilan, kesetiaan, kasih (ay. 22). Sehingga dalam segala sesuatu yang anak muda lakukan dalam gereja, anak muda mampu menjadi pemimpin yang dapat diteladani dan tidak akan direndahkan hanya karena perbedaan usia dan sikap. 
Dengan demikian, kaum muda mampu menjadi pemimpin jika ia memusatkan Tuhan dalam hidupnya, dan siap menghadapi tantangan. la akan mengubah sikap hidup, cara berpikir, dan moral yang ada di gereja yang semakin hari semakin menyimpang dari tujuannya. Dengan mengetahui visi Allah dalam dirinya, ia mampu mempromosikan imannya percayanya kepada Yesus terhadap orang-orang yang ada di sekitarnya. Serta mampu membawa gereja-gereja atau orang-orang yang telah menyimpang dari jalan yang benar kembali menyembah Allah Sang Pencipta.

Roma 12:1-2 menjelaskan tentang ibadah yang sejati adalah dengan mempersembahkan hidupnya yang kudus dan yang berkenan kepada Allah. Tidak menjadi serupa dengan zaman dunia saat ini tetapi adanya perubahan dalam hidup dan akal budi sehingga mengetahui yang mana kehendak Allah dan yang bukan. Rasul Paulus dalam Kolose 1:28-29 menjelaskan bagaimana ia mengajari dan menasihati dalam hikmat orang-orang tersebut untuk dapat memimpin orang-orang tersebut kepada kesempurnaan dalam Kristus. Setiap orang dipilih untuk memimpin tiap-tiap orang agar hidup seperti Kristus dan semakin hari semakin sama seperti Kristus.

\section{KESIMPULAN}

Berdasarkan pembahasan dari kajian narasi tentang kepemimpinan Yosia berdasarkan kitab 2 Tawarikh 34:1-7 dan implikasinya bagi kepemimpinan pemuda di gereja, maka dapat ditarik sebagai kesimpulan sebagai berikut. Pertama, Tuhan memakai kaum muda. Yosia beroleh kesempatan dan menjadi seorang pemimpin di masa mudanya. Hal ini menjadi dorongan besar bagi gereja seharusnya untuk mampu melibatkan pemuda lebih lagi dalam gereja dan dalam pelayanan. Kedua, dalam kaitannya bagi kepemimpinan pemuda, pemimpin harus memusatkan hidup pada Tuhan. Dengan itu, apa yang seorang pemimpin kejar adalah kekudusan, kejujuran dan perkenanan Tuhan - bukan manusia. Ketiga, masih berkaitan dengan kepemimpinan pemuda, pemimpin harus siap menghadapi tantangan. Teknologi saat ini menjadi tantangan besar bagi kaum muda jika dimanfaatkan dengan buruk. Oleh karena itu, perlu kebijaksaan dalam penggunaannya; pemanfaatan bagi pertumbuhan rohani akan sangat bijaksana. Selain itu, ada juga tantangan kekuasaan dalam gereja. Gereja harus memberikan kesempatan bagi pemuda dalam melayani. Sedangkan pemuda, harus menjadikan hubungan dengan Tuhan dan sesama sebagai prioritas, bukannya kekuasaan.

\section{KEPUSTAKAAN}

Bakker, F. L. (2004). Sejarah Kerajaan Allah 1: Perjanjian Lama. Jakarta: BPK Gunung Mulia.

Bergant, D., dan Karris, R. J. (2002). Tafsir Alkitab Perjanjian Lama. Yogyakarta: Kanisius. 
Browning, W. R. F. (2007). Kamus Alkitab: A dictionary of the Bible. Jakarta: BPK Gunung Mulia.

Buttrick, G. A. (1952). The Interpreter's Bible-The Holy Scriptures in the King James and Revised Standard Versions with General Articles and Introduction, Exegesis, Exposition for each Book o the Bible. Nashville: Abingdon Press.

Carson, D. A. (ed.). (1994). New Bible commentary: 21st century edition (4th ed). Illinois: InterVarsity Press.

Clarke, A. (ed.). (1977). The Holy Bible. Nashville: Abingdon Press.

Douglas, J. D. (1995). Ensiklopedia Alkitab Masa Kini Jilid II. Jakarta: Yayasan Komunikasi Bina Kasih.

Eynikel, E. (1996). The Reform of King Josiah and the Composition of the Deuteronomistic History. Netherlands: BRILL.

Frances, B. (2007). Inti Alkitab Untuk Para Pemula. Jakarta: BPK Gunung Mulia.

Free, J. P. (2001). Arkeologi dan Sejarah Alkitab. Malang: Gandum Mas.

Goldingay, J. (2012). 1 and 2 Chronicles for Everyone. UK: SPCK Publishing.

Gunawan, D. (2014). Roh Inspirasi Anda Agar Hidup \& Usaha Lebih Sukses. Jakarta: Elex Media Komputindo.

Henry, M., \& Scott, T. (1979). Commentary on the Holy Bible. Nashville: Thomas Nelson Publishers.

Hocking, D. (1993). Rahasia Keberhasilan Seorang Pemimpin: 7 Hukum Kepemimpinan Rohani. Yogyakarta: Yayasan ANDI.

Lasor, W. S., Hubbard, D. A., \& Bush, F. W. (2008). Pengantar Perjanjian Lama 1. Jakarta: BPK Gunung Mulia.

Lie, T. G. (2017). Generasi ke Generasi. Bandung: PT Visi Anugerah Indonesia.

Lumintang, S. I. (2015). Theologia Kepemimpinan Kristen. Jakarta: Geneva Insani Indonesia.

Maclaren, A. (n.d.). Expositions Of Holy Scripture. Michigan: Baker House.

Mahda, A. (2017). Pulang. Sukabumi: CV Jejak.

https://books.google.com/books/about/

Pulang.html?hl=id\&id=4_xtDwAAQBAJ).

Mandryk, J. (2013). Operation World: Panduan untuk Mendoakan Semua Bangsa di Dunia [Edisi ke-7]. Yogyakarta \& Surabaya: Katalis Media \& Literature - Yayasan Gloria.

Maxwell, J. C. (2014). Semua Orang Memimpin. Jakarta: BPK Gunung Mulia.

Park, A. (2018). Pemeliharaan yang Misterius dan Ajaib: Silsilah Yesus Kristus (II), Sejarah Raja-raja. Depok: Yayasan Damai Sejahtera Utama.

Peramesti, Ni Putu Depi Yulia dan Dedi Kusmana. (2018). Kepemimpinan Ideal Pada Era Generasi Milenial. Transformasi: Jurnal Manajemen Pemerintahan, 10(1), 73-

84. http://ejournal.ipdn.ac.id/JTP/article/download/413/243.

Pfeiffer, C. F., \& Harrison, E. F. (2004). The WYCLIFFE Bible Commentary-Tafsiran Alkitab Wycliffe Volume 1. Malang: Gandum Mas.

Prasetya Pr., L. (2006). Panduan Untuk Calon Baptis Dewasa. Yogyakarta: Kanisius. 
Rahzen, T., \& Hartono, A. (2011). Strategi Pemberdayaan Komunitas Adat. Direktorat Jenderal Kebudayaan.

Sitompul, R. (2017). Pelayanan Pemuda di Era Teknologi Digital. Jurnal Antusias, 5(1), 1-16. https://sttintheos.ac.id/e-journal/index.php/antusias/article/view/153/0.

Strauss, R. L. (2011). Bagaimana Memahami Kehendak Tuhan. Jakarta: BPK Gunung Mulia.

Surbakti, E. B. (2006). Benarkah Yesus Juruselamat Universal? Jakarta: BPK Gunung Mulia.

Sutanto, H. (2007). Hermeneutik: Prinsip dan Metode Penafsiran Alkitab. Malang: Literatur SAAT.

Sweeney, M. A. (2001). King Josiah of Judah: The lost messiah of Israel. UK: Oxford University Press.

Tacoy, S. M. (2009). 6 Kunci Sukses Melayani Kaum Muda. Bandung: Yayasan Kalam Hidup.

Tobing, O. L., \& Yosia, T. (2017). Konstitusi Reformasi Yehuda Abad ke-7 sM (2 Rajaraja 22:1-23:30). Marampa, 1, 17-31.

https://www.academia.edu/36930479/KITAB_TAURAT_YOSIA_Konstitusi_Reform asi_Yehuda_Abad_ke_7_sM_2_Raja_raja_22_1_23_30_Jurnal_Marampa_vol_1_Thn_ 2017.

Tua, E. M. (2017). Respon Daud Dalam Menghadapi Pergumulan: Studi Terhadap Kitab Mazmur 3:1-9. Evangelikal: Jurnal Teologi Injili dan Pembinaan Warga Jemaat, 1(1), 75-84.

https://journal.sttsimpson.ac.id/index.php/EJTI/article/download/59/43.

Wiersbe, W. W. (2014). Hidup Bersama Firman: Pasal demi Pasal Seluruh Alkitab. Yogyakarta \& Surabaya: Katalis Media \& Literature - Yayasan Gloria.

Wijaya, H. (2015). Keunggulan Integritas Generasi Muda Dalam Mewujudkan Kepemimpinan Rohani Yang Bertanggungjawab. Sekolah Tinggi Filsafat Jaffray Makassar. https://doi.org/10.13140/rg.2.1.4264.9048.

Wijaya, Y. (2018). Kepemimpinan Yesus Sebagai Acuan Bagi Kepemimpinan Gereja Masa Kini. Jurnal Jaffray, 16(2), 129-144. http://dx.doi.org/10.25278/jj71.v16i2.287.

Zaluchu, S. (2018). Respons Tests of Leadership Menurut Teori Frank Damazio Pada Mahasiswa Pascasarjana Jurusan Kepemimpinan Kristen STT Harvest Semarang. Jurnal Jaffray, 16(2), 145-160. http://dx.doi.org/10.25278/jj71.v16i2.289.

Zalukhu, E. (2017). I'm a Leader: Melatih Manajer Andal Menjadi Pemimpin Hebat Dan Terampil Dalam Menggerakkan Perubahan Untuk Meningkatkan Kinerja Tim Dan Perusahaan. Jakarta: Gramedia Pustaka Utama. 